\title{
Clinical Study on the Effect of Regular Hemodialysis in Renal Failure
}

\author{
-The Effect of Hemodialysis on Oxygen Carrying Capacity- \\ Takao TANAKA ${ }^{1}$, Akio Shigematsu ${ }^{1}$ and Kiichiro IChimaru ${ }^{2}$ \\ ${ }^{1}$ Department of Anesthesiology, School of Medicine, University of Occupational \\ and Environmental Health, Japan. Kitakyushu 807, Japan \\ ${ }^{2}$ Kurosaki Clinic. Kitakyushu 806, Japan
}

\begin{abstract}
The effect of hemodialysis on oxygen carrying capacity has been studied in 10 patients with chronic renal failure (CRF). $\quad P_{50}$ which indicates oxygen affinity of hemoglobin $(\mathrm{Hb})$ and $\mathrm{PO}_{2}$ were significantly reduced in the postdialysed state while the $\mathrm{pH}$ value was significantly elevated. Both intraerythrocytic 2, 3-diphosphoglycerate (2,3-DPG) and $\mathrm{PCO}_{2}$ were slightly reduced after hemodialysis although these two parameters did not show the statistically significant change. From the results of this study, it is concluded that the return of the oxygen dissociation curve (ODC) toward the left after hemodialysis was induced mainly by the $\mathrm{pH}$ change (Bohr effect).
\end{abstract}

Key words: hemodialysis, oxygen dissociation curve, 2,3-DPG, $\mathrm{pH}$.

(Received 12 March 1980)

\section{Introduction}

The number of the patients undergoing regular hemodialysis due to chronic renal failure (CRF) has lately become greater than before and must be considered one of our social problems. Many reports on the pathophysiological and biochemical changes in the subjects with CRF have been published by many other authors and some new informations are being accumulated (Blumberg \& Marti, 1972; Rodriguez-Commes et al., 1979).

In the present report, the authors intend to introduce some of the results of their recent clinical study - with special reference to the changes of oxygen carrying capacity in those uremic patients before and after regular hemodialysis.

\section{Materials and Method}

Ten adult patients were randomly chosen from the subjects undergoing regular hemodialysis (3 times a week, 5 hours for each) due to CRF. The oral consent to this experiment was obtained from all the patients prior to the study.

The heparinized blood samples $(3 \mathrm{ml})$ before hemodialysis were drawn from the arterial line which were immediately placed on an ABL-2 automatic blood gas analyzer (Radio- 
Table 1. The changes of parameters measured before and after hemodialysis in 10 uremic patients. The values were compared with each other before and after dialysis by a paired t-test. (mean \pm s. D.)

\begin{tabular}{cccl}
\hline & Predialysis & Postdialysis & \\
\hline $\mathrm{Hb}(\mathrm{g} / \mathrm{dl})$ & $6.85 \pm 1.47$ & $7.04 \pm 1.91$ & N.S. \\
$\mathrm{pH}$ & $7.28 \pm 0.03$ & $7.41 \pm 0.03$ & $p<0.05$ \\
$\mathrm{Po}_{2}$ (torr) & $122.26 \pm 18.28$ & $91.31 \pm 17.56$ & $p<0.005$ \\
$\mathrm{PCO}_{2}$ (torr) & $33.45 \pm 2.07$ & $31.57 \pm 2.22$ & N.S. \\
$\mathrm{P}_{50}$ (torr) & $32.05 \pm 2.79$ & $29.60 \pm 2.07$ & $p<0.001$ \\
$2,3-\mathrm{DPG}(\mathrm{mg} / \mathrm{g} \cdot \mathrm{Hb})$ & $4.96 \pm 0.70$ & $4.70 \pm 0.64$ & N.S. \\
\hline
\end{tabular}

N.S. : statistically not significant

meter) for the measurements of $\mathrm{Hb}, \mathrm{pH}, \mathrm{PO}_{2}$ and $\mathrm{PCO}_{2}$.

The oxygen dissociation curve (ODC) was obtained by use of an automatic oxygen dissociation analyzer (TCS Hemox-Analyzer) and only 50-70 $\mu 1$ of blood samples in $4 \mathrm{ml}$ of Hemox-buffer solution were used. $\mathrm{P}_{50}$, the partial pressure at which $50 \%$ of hemoglobin is saturated with oxygen $\left(37^{\circ} \mathrm{C}\right.$, pH 7.4) was determined by analysing ODCs.

Intraerythrocytic 2,3-DPG concentration was measured by the modified Keitt's enzymatic end point method using Boehringer-Mannheim 2,3-DPG assay kit.

Immediately after hemodialysis was finished, the blood samples from the same arterial line were drawn again and the same measurements were performed. The values obtained in this study were statistically analysed by a paired t-test.

\section{Results}

The results obtained in the present study are shown in Table1 1.

The $\mathrm{Hb}$ concentration of the blood increased slightly in the postdialysed state although the difference was not statistically significant. Both $\mathrm{PCO}_{2}$ and 2,3-diphosphoglycerate were reduced after dialysis although these two parameters did not show statistically significant difference. On the other hand, the $\mathrm{pH}$ value, $\mathrm{P}_{50}$ and $\mathrm{PO}_{2}$ were significantly changed $(P<0.05, P<0.001$ and $P<0.005$, respectively).

\section{Discussion}

It is widely known that persistent anemia (normocytic and normochromic in many cases) is frequently found in CRF mainly due to reduced renal erythropoietin production, shortened life span of erythocytes, malnutrition and so forth. In these patients, increased cardiac output and rightward shift of ODC to meet the peripheral tissue oxygen demands have been reported (Blumberg \& Marti, 1972).

In the present study, lowered $\mathrm{Hb}$ and increased 2,3-DPG were observed in these ure- 
mic patients similarly as in the previous papers reported by others (Blumberg \& Marti, 1972; Blumberg \& Keller, 1979) and these phenomena may be closely related with chronic nephrogenic anemia. 2,3-DPG which regulates oxygen affinity of $\mathrm{Hb}$ is known to be synthetized by the DPG mutase in the Rapoport-Luebering (2,3-DPG) cycle (Benesch \& Benesch, 1967; Chanutin \& Curnish, 1967). Increased 2,3-DPG is reported to shift the ODC rightward, reducing oxygen affinity of $\mathrm{Hb}$.

The intraerythrocytic concentration of 2,3-DPG, however, did not change significantly before and after hemodialysis in this study. It is anticipated that 2,3-DPG remains in red blood cells during hemodialysis because of the protective function of erythrocyte membranes.

The marked reduction of $\mathrm{P}_{50}$ after dialysis was, therefore, considered due to the $\mathrm{pH}$ change (Bohr effect). Reduced $\mathrm{pH}$ (increased $\mathrm{H}^{+}$) may change the pKs (dissociation constant) of $\alpha$-amino group at $\alpha_{1}$-valine, and of imidazole groups at $\alpha-122$ and $\beta-146$ histidines, all of which may strongly affect oxygen affinity of $\mathrm{Hb}$.

Increased $\mathrm{H}^{+}$is considered to release oxygen from $\mathrm{Hb}$ by binding to these Bohr amino groups of $\mathrm{Hb}$ (Perutz, 1970). The Bohr coefficient $\left(\Delta \log \mathrm{P}_{50} / \Delta \mathrm{pH}\right)$ has been reported as approximately -4.0 which means that $\mathrm{P}_{50}$ will be shifted about 3 torr by the $\mathrm{pH}$ change of 0.1. (Tyuma, 1975). If cardiac output remains unchanged, the decrease of $\mathrm{P}_{50}$ as seen in the postdialysed state seems unfavorable to the body in respect to tissue oxygen supply.

Recently, Blumberg \& Keller (1979) reported that cardiac index is increased after hemodialysis which may play a major role in making up for the decrease of $\mathrm{P}_{50}$ (leftward shift of ODC) as observed in the present study. Therefore, it is concluded from the present study that the reduction of $\mathrm{P}_{50}$ induced by the $\mathrm{pH}$ normalization in the postdialysed state is compensated by the possible increase of cardiac output in the subjects of CRF and the change of $2,3-\mathrm{DPG}$ seemed to play a minor role in the shift of ODC during the dialysis procedure.

As for the decrease of $\mathrm{Po}_{2}$, it is supposed that leucocyte segregation in the pulmonary capillary vessels and the loss of $\mathrm{CO}_{2}$ through the membrane dialyser which may virtually induce hypoventilation are the possible causes as Craddock et al. (1977) and Aurigemma et al. (1977) proposed.

\section{References}

Aurigemma, N. M., Feldman, N. T., Gottlieb, M. et al. (1977): Arterial oxygenation during hemodialysis. New Engl. J. Med., 297: 871-873.

Benesch, R. \& Benesch, R. E. (1967): The effect of organic phosphates from the human erythrocyte on the allosteric properties of hemoglobin. Biochem. Biophys. Res. Commun., 26: 162-167.

Blumberg, A. \& Marti, H. R. (1972): Adaptation to anemia by decreased oxygen affinity of hemoglobin in patients on dialysis. Kidney Int., 1: 263-270.

Blumberg, A. \& Keller, G. (1979): Oxygen consumption during maintenance hemodialysis. Nephron, 23: $276-281$.

Chanutin, A. \& Curnish, R. R. (1967): Effect of organic and inorganic phosphates on the oxygen equilibrium of human erythrocytes. Arch. Biochem. Biophys., 121: 96-102.

Craddock, P. R., Fehr, J., Brigham, K. L. et al. (1977): Complement and leucocyte-mediated pul- 
monary dysfunction in hemodialysis. New Engl. J. Med., 296: 769-774.

Perutz, M. F. (1970): Stereochemistry of cooperative effects in hemoglobin. Nature, 228: $726-739$.

Rodriguez-Commes, J. L., Tabernero, J. M., Martin-Vasallo, P. et al. (1979): Metabolism of red blood cells in chronic renal failure. Nephron, 24: 21-24.

Tyuma, I. (1975): Oxygen transport activity of the blood. Anesthesia and Reanimation Seminar. 6: $1-15$.

血液透析效果の臨床的検討

一酸素運搬能に及ぼす影響—

由中 孝夫 ${ }^{1}$ ・重松 昭生 ${ }^{1}$ 。术丸鼔一郎 ${ }^{2}$

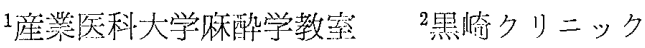

要旨：血液透析療養中の成人10名において向液透析舆作の血液酸素運搬能に対する影響を検討し た.その結果， $\mathrm{P}_{50}$ および $\mathrm{PO}_{2}$ は透析後有意な低下を示した。赤血球内 $2,3-\mathrm{DPG}$ お よび $\mathrm{PCO}_{2}$ に有意な変化を認めえなかったととから，酸素解離曲線の透析後の左方移動は 主に pH の変化 Bohr 効果によるととろが大きいと考光られた。事実，今回の検討でも $\mathrm{pH}$ は透析後有意の上景（正労化）を示した。

J. UOEH（雇業医大誌），2（2）：211-214（1980） 